\title{
Meme kitle muayenesi: histopatolojik analiz
}

Gurmeet Singh SARLA ${ }^{1}$

\begin{abstract}
$\ddot{\mathbf{O z}}$
Maharashtra/ Nasik bölgesindeki periferik bir hastanenin cerrahi bölümünde küçük göğüs kitlesi nedeniyle eksizyonel biyopsi yapılan hastaların histolojik tanılarının gözden geçirilmesi. $\mathrm{Bu}$ çalışma biyopsi metaryallerinin, histopatolojik raporlarının 2 yıllık bir döneminin incelendiği retrospektif bir çalışmadır. İki y1llık dönem geriye doğru tarandı. Memede kitle ile başvuran 20-60 yaşları arasındaki toplam 90 hastanın eksizyon biyopsisi raporuna ulaşıldı ve çalışmaya alındı. 35 hastaya sağ ve 55 hastaya sol meme kitlesi nedeniyle biyopsi yapıldığı tespit edildi. Histolojik tanılar incelendiğinde 88 hastanın $(\% 97,77)$ benign, 2 hastanın ise malign tümörünün (\% 2,22) olduğu saptand1. Fibroadenom en sık görülen benign tümördü ve filloides tümörü nispeten nadirdi. Fibroadenomalı hastaların yaşları 20 ile 40 arasındaydı. Karsinomu olan 2 hastanın biri 40 yaş altı, diğeri 50 yaşın üzerindediydi. Fibroadenom, fibroadenosis, filloides tümörleri vb gibi benign meme hastalıkları yaygın görülen meme kitleleridir ve tüm meme kitleleri kanser değildir. 40 yaşın üzerindeki hastalarda meme kanseri ve meme kitleleri için yaş önemli bir belirleyicidir, bu yaş hastalara eksizyon biyopsisi ve histopatolojik inceleme yapılmalıdır. Tümör kitlesinin histopatolojik analizinin önemi üzerinde fazla durulmamıştır. Kitle büyüklüğündeki artış, artan yaşla orantılıdır.
\end{abstract}

Anahtar Kelimeler: Meme kitlesi, benign meme hastalı̆̆ı, fibroadenoma, fibroadenosis

\section{Breast lump excision: histopathological analysis}

Gurmeet Singh SARLA ${ }^{1}$

\begin{abstract}
The presence of a lump in the breast is a great cause of anxiety and apprehension in females. Of these lumps, the most important diagnosis is cancer of the breast and the most common lumps are benign. The aim of this study is to review and analyse the histological diagnosis of breast lumps of patients seen in the department of surgery in a peripheral hospital in Nasik, Maharashtra. This is a retrospective study covering a period of 2 years wherein histopathology reports of 90 patients aged 20-60 years who presented with breast masses underwent excision biopsy in the department of surgery in a peripheral hospital in Nasik, Maharashtra were studied. During the 2-year period, 90 patients aged 20-60 years who presented with breast masses underwent excision biopsy. 35 patients had right sided breast lumps, while the left breast was involved in 55 cases. The histological diagnosis showed that 88 patients $(97.77 \%)$ had benign disease while 2 had malignant tumours (2.22\%). Fibroadenoma was the commonest benign tumour encountered, phyllodes tumour was relatively uncommon. The ages of patients with fibroadenoma ranged from 20 to 40 years .Of the 2 patients who had carcinoma, one was below the age of 40 years and the other one was above 50 years of age. Benign breast diseases, i.e., fibroadenoma, fibroadenosis, phyllodes tumour are the commoner breast diseases and not all breast lumps are cancerous. Age is a strong determinant of risk for breast cancer and breast lumps in patients above 40 years of age should be offered excision biopsy and subsequent histopathological examination. The importance of histopathological analysis of lumps cannot be overemphasized. The increase in the size of the lump increases proportionately with increasing age.
\end{abstract}

Keywords: Breast lump, benign breast disease, fibroadenoma, fibroadenosis

${ }^{1}$ Classified Specialist Surgery, Military Hospital Devlali, Devlali Cantt Nasik, Maharashtra, Pin 422401,India

Corresponding Author

Gurmeet Singh SARLA 


\section{INTRODUCTION}

The presence of a lump in the breast is a great cause of anxiety and apprehension in females, young and old. ${ }^{1}$ Of these lumps, the most important diagnosis is cancer of the breast. ${ }^{1}$ Benign breast disease is the most common cause of breast problems and up to $30 \%$ of women will suffer from benign breast disorder requiring treatment at some time in their lives. Benign lesions of Breast are classified into nonproliferative lesions which include Fibrocystic disease and cysts and proliferative lesions which include Fibroadenoma, Phylloides tumour and Ductal Ectasia. ${ }^{2}$ Carcinoma of Breast is extremely rare below 20 years of age but thereafter the incidence steadily rises so that by the age of 90 years nearly $20 \%$ women are affected. Prognosis of Breast cancer is closely related to stage at diagnosis. Fibroadenomas are rarely seen as new masses in women after the age of 40-45 years. ${ }^{3}$ Clinically they present as firm masses that are easily movable and may increase in size over a period of several months. ${ }^{3}$ On excision, fibroadenomas are well encapsulated masses that may detach easily from surrounding breast tissue. $^{3}$ Literature reveals that approximately $10 \%$ of breast lumps ultimately lead to a diagnosis of breast cancer. ${ }^{4}$ The aim of this study is to impress upon that not all breast lumps are cancerous and majority of breast lumps are benign. Age is a strong determinant of risk for breast cancer and breast lumps in patients above 40 years of age should be offered excision biopsy and subsequent histopathological examination.

\section{MATERIALS AND METHODS}

This is a retrospective study of all patients with breast lumps seen in the department of surgery at a peripheral hospital in Nasik, Maharashtra from 2016 to 2018 . Only one surgeon attended to the patients. They were examined in the clinic, before being scheduled for excision. Most of the biopsies were done under LMA. The specimens collected were sent to the histopathology laboratory for histopathological examination. Patient information was obtained from department of General Surgery and Histopathology reports were obtained from the department of Pathology Military Hospital Devlali.

Ethical Approval : Approval for the study was granted by Military Hospital Devlali Ethics Committee (+919717121247), and permission to analyze the histopathological reports of the patients was taken from the Pathologist of the hospital who reported upon these specimens.

\section{RESULTS}

During the 2-year period, a total of 90 patients aged 20-60 years who presented with breast lumps or masses underwent excision biopsy. All 90 patients were females. 35 patients had right breast lumps, while the left breast was involved 
in 55 cases ( Figure 1). All patients had their operative procedure under LMA. The histological diagnosis showed that 88 patients (97.77\%) had benign disease while 2 had malignant tumours $(2.22 \%)$ (Table 2). Fibroadenoma was the commonest benign tumour encountered, phyllodes tumour was relatively uncommon (Table 2). The ages of patients with fibroadenoma ranged from 20 to 40 years (Table 1). Of the 2 patients who had carcinoma, one was below the age of 40 years, and the other one was above 50 years of age (Table 1).

Out of 90 patients, 35 patients $(38.88 \%)$ presented with Right sided lump whereas 55 patients $(61.11 \%)$ presented with Left sided lump (Figure 1).

\section{DISCUSSION}

Patients complaining of breast disorders form a large proportion of out-patients in general surgical clinics. The presence of a lump in the breast is a great cause of anxiety and apprehension in females. Public awareness of breast cancer has contributed largely to this, and the consequence is a steady flow of frightened females attending surgical outpatient clinics, with complaints of cyclical mastalgia, nodularity, or asymmetry, but a small proportion will indeed present with breast lumps. ${ }^{1}$ Breast lumps are a common finding in women of all ages, but are particularly common during the reproductive years (from menarche to menopause). In our study all patients were of the reproductive age group and nobody had attained menopause. Of these lumps, the most important diagnosis is cancer of the breast. Having a breast lump does not automatically mean a patient has breast cancer, as only $10 \%$ of people presenting with breast lumps turn out to have breast cancer.

Most breast lumps are benign breast disease, a range of conditions that can cause breast lumps but are not cancerous. However, some benign breast diseases are associated with a slightly increased risk of cancer in the future, depending on that patient's medical history, family history and risk factors. Benign breast disease is the most common cause of breast problems and upto $30 \%$ of women will suffer from benign breast disorder requiring treatment at some time in their lives. The most common symptoms are pain, lumpiness or a lump. Patients with a lump, nipple discharge, or mastalgia represent a considerable workload in general surgery. ${ }^{1}$ Fear of breast cancer causes a great increase in the number of patients attending surgical clinics, especially the young. ${ }^{1}$ Even though cancer of the breast is strongly age related, majority of the patients seen in this study were young, under the age of 40 years. Excision of the breast lumps was performed and they were labelled as benign or malignant based on the histopathology report. The American Cancer Society (ACS) estimates that 182,460 women in the United States were 
diagnosed with breast cancer in 2008 and that 40,480 women died of the disease during the year. ${ }^{5}$ The incidence of breast cancer appears to have a sigmoid function in women less than 55 years of age with $6.6 \%$ of all cases diagnosed before age 40, 2.4\% diagnosed before age 35, and $1 \%$ diagnosed before age $30 .{ }^{6}$ The individual average risk of a woman developing breast cancer was 1 in 173 by the age of 40 and approximately 1 in 1,500 by the age of $30 .^{6}$ Breast cancer at an early age is more likely to be associated with an increased familial risk, especially in women harboring a germline $B R C A 1$ mutation. ${ }^{7}$ In a study of women with breast cancer diagnosed before age 30, BRCA1, BRCA2, and TP53 mutations were found in about half who had strong family histories of breast cancer and in less than $10 \%$ of women with non-familial breast cancer. ${ }^{8}$

The Histopathology reports showed that 88 patients $(97.77 \%)$ had benign breast disease, while 2 patients $(2.22 \%)$ had malignant disease. This demonstrates that benign mammary lesions occurred more frequently than the malignant ones. Most of the breast lesions occurred in young patients, especially those aged 20-30 years and majority were fibroadenomas (60\%). Hyperplastic lobules were shown to be histologically identical with fibroadenomas, ${ }^{9}$ which are thought to be hyperplastic lesions associated with aberration of the normal maturation of the breast, rather than true neoplasms. There are two subtypes of fibroadenomas: Giant fibroadenomas that attain unusually large size, typically greater than ${ }^{5} \mathrm{~cm}$ and juvenile fibroadenomas that occur in adolescents and young adults and histologically are more cellular. Phyllodes tumours have been described as rare fibroepithelial tumours that account for about $1 \%$ of all breast neoplasms. ${ }^{9}$ Phyllodes tumour contain a biphasic proliferation of stroma and mammary epithelium. First called Cystosarcoma Phyllodes, the name has been changed to phyllodes tumour in recognition of its usually benign course. ${ }^{3}$ However with increasing cellularity, an invasive margin and sarcomatous appearance, these tumours may be classified as malignant phyllodes. $^{3}$ Benign phyllodes tumours are recognised as firm, lobulated masses that can range in size with an average size of approximately $5 \mathrm{~cm}$ (larger than average fibroadenoma). ${ }^{3}$ Histologically these tumors are similar to fibroadenoma but the whorled stroma forms larger clefts lined by epithelium that resembles clusters of leaflike structures. The sarcoma is more cellular than a fibroadenoma, but fibroblastic cells are bland and mitoses are infrequent. Ductal Ectasia presents with palpable lumpiness beneath the areola. ${ }^{2}$ Nipple discharge is a common feature with periductal scarring and inflammation and progresses to destruction and dilatation of the ductular system and eventually periductal fibrosis and ectasia. ${ }^{2}$ These lesions typically occur in peri-menopausal or late premenopausal age groups. ${ }^{2}$ 
The usual management of a dominant breast mass is based on the assumption that the mass is cancerous until proven otherwise. ${ }^{10}$ While most reports indicate that breast lumps are predominantly benign and mostly nonproliferative epithelial lesions, there has, however, been an increasing recognition of the risk of developing cancer from the various forms of premalignant lesions, especially atypical ductal and atypical lobular hyperplasia. ${ }^{11} \mathrm{~A}$ new system has been developed and described by the Cardiff Breast Clinic - ANDI (Aberrations of normal development and involution) involves disturbances in the breast physiology extending from an extreme of normality to well defined disease processes. ${ }^{12}$ The disease consists of 4 features which vary in extent and degree in any one breast: Cyst formation, Fibrosis, Hyperplasia, Papillomatosis. Many alternative terms have been applied to this condition including fibrocystic disease, fibroadenosis, chronic mastitis and mastopathy. ${ }^{12}$ The symptoms of ANDI include an area of lumpiness and/or breast pain (mastalgia). Cancer of the breast under the age of 30 is extremely rare and carcinoma under the age of 20 might be considered a medical curiosity. ${ }^{13}$

Fibroadenomas are benign solid tumours composed of stromal and epithelial elements. ${ }^{3}$ Fibroadenoma is the second most common tumour in the breast after carcinoma and is the most common tumour in women younger than 30 years. ${ }^{3}$ Fibroadenomas most often arise in late teens and in women during their early reproductive years. They present as well encapsulated, firm, movable masses which may increase in size over a period of several months. In the adolescent population, the overall incidence of fibroadenoma is $2.2 \%{ }^{14}$ They account for $68 \%$ of all breast masses and $44 \%-$ $94 \%$ of biopsied breast lesions. ${ }^{15}$ The exact etiology of fibroadenoma is unknown. However, several studies show that estrogen influences the development of fibroadenomas. ${ }^{16}$ Fibroadenomas usually form during menarche, a time when lobular structures are added to the ductal system of the breast.

It is important for surgeons to recognize and distinguish benign and premalignant lesions from breast cancer through biopsy. This study, therefore, reviews the histological diagnosis of breast lumps of patients seen in the department of surgery at a peripheral hospital in Nasik, Maharashtra from 2016 to 2018, a period of 2 years. It is also believed that the result of this analysis will further improve experience in advising patients about the correct attitude toward breast lumps in all ages.

\section{CONCLUSION}

This study shows that not all breast lumps are cancerous and majority of breast lumps in our study are benign (Table 2). Age is a strong determinant of risk for breast cancer (Table 1) and breast lumps in patients above 40 years of 
age should be offered excision biopsy and subsequent histopathological examination. The importance of histopathological analysis of lumps cannot be overemphasized, especially by the uncommon findings of breast cancer in two females wherein one was below the age of 40 years, and the other one was above 50 years of age. The increase in the size of the lump increases proportionately with increasing age (Table 3).

\section{REFERENCES}

1. Njeze GE. _Breast Lumps: A 21 -year single center clinical and histological analysis. Nigerian J of Surg. 2014;38-41.

2. Swartz SI, Shires GT, Spencer FC, Daly JM, Fischer JE, Galloway AC. Breast In :International ed. Principles of Surgery. $7^{\text {th }}$ ed.Vol.1; 1999: 550-552.

3. Courtney M Townsend, R Daniel Beauchamp, B Mark Evers, Kenneth L Mattox. Diseases of the Breast In: Restricted South Asia ed. $19^{\text {th }}$ ed. Sabiston Textbook of Surgery The Biological Basis of Modern Surgical Practice. Vol1: 2012; 839.

4. Barton MB, Elmore JG, Fletcher SW. Breast symptoms among women enrolled in a health maintenance organization: frequency, evaluation, and outcome. Ann Intern Med. 1999;130:651-7.

5. Jemal A, Siegel R, Ward E, et al. Cancer statistics, 2008. CA Cancer J Clin. 2008;58:7196.

6. Ries L, Melbert D, Krapcho M, et al. SEER Cancer Statistics Review, 1975-2005. National Cancer Institute; Bethesda, based on November 2007 SEER data submission, posted to the SEER website, 2008.

7. Antoniou A, Pharoah PD, Narod S, et al. Average risks of breast and ovarian cancer associated with BRCA1 or BRCA2 mutations detected in case series unselected for family history: a combined analysis of 22 studies. Am J Hum Genet. 2003;72:1117-30.

8. Lalloo F, Varley J, Moran A, et al. BRCA1, BRCA2 and TP53 mutations in very earlyonset breast cancer with associated risks to relatives. Eur J Cancer. 2006;42:1143-50.

9. Hughes LE, Mansel RE, Webster DJ. Aberration of normal development and involution: A new perspective on pathogenesis and nomenclature of benign breast disorders. Lancet. 1987;2:1316-9.

10. Canny PF, Berkowitz GS, Kelsey JL, LiVolsi VA. Fibroadenoma and the use of exogenous hormones: A case control study. Am J Epidemiol. 1988;127:454-61.

11. Parker SJ, Harris SA. Phyllodes tumors. Postgrad Med J. 2001;77:4258-435.

12. Ralph EL, Daniel RS, Wilma D, Kent CW, Nicholas PL. Breast masses in young women. Am J Surg. 1980;140:779-82. 
13. Dupont WD, Parl FF, Hartmann WH, et al. Breast cancer risk associated with proliferative breast disease and atypical hyperplasia. Cancer. 2006;71:1258-65.

14. Russell RC, Williams NS , Bulstrode CK. The Breast In:International students ed. Bailey \& Love's Short Practice of Surgery. 23 ${ }^{\text {rd }}$ ed:2000; 758
15. Stephens WP, Breast lumps in adolescent girls. $\mathrm{Br} \quad$ Med J. 1978;1:260-1.PMCID : PMC1602749

16. Santen RJ, Mansel R. Benign breast disorders. N Engl J Med. 2005;353(3):275285. 
Table 1. Age distribution of patients with Breast Lumps.

\begin{tabular}{lll}
\hline Age in years & Number & Percentage \\
\hline $21-30$ years & 30 & $33.33 \%$ \\
$31-40$ years & 24 & $26.66 \%$ \\
$41-50$ years & 27 & $30 \%$ \\
$51-60$ years & 9 & $10 \%$ \\
Total & 90 & $100 \%$
\end{tabular}

\section{Table 2. Distribution of histological types.}

$\begin{array}{lll}\text { Histopathology } & \text { Number } & \text { Percentage }\end{array}$

Fibroadenoma

54

$60 \%$

Fibrocystic disease 
Table 3. Co-relation of size of the lump to age of the patient.

\begin{tabular}{lll}
\hline Age of the patient & Size of the lump & Percentage \\
\hline $21-30$ years & $2 \mathrm{~cm}$ & $62.5 \%$ \\
& $3 \mathrm{~cm}$ & $66.66 \%$ \\
$31-40$ years & \\
$41-50$ years & $4 \mathrm{~cm}$ & $64 \%$ \\
& \\
$51-60$ years & $5 \mathrm{~cm}$ & $68.4 \%$
\end{tabular}


60

50

40

30

20

10

0

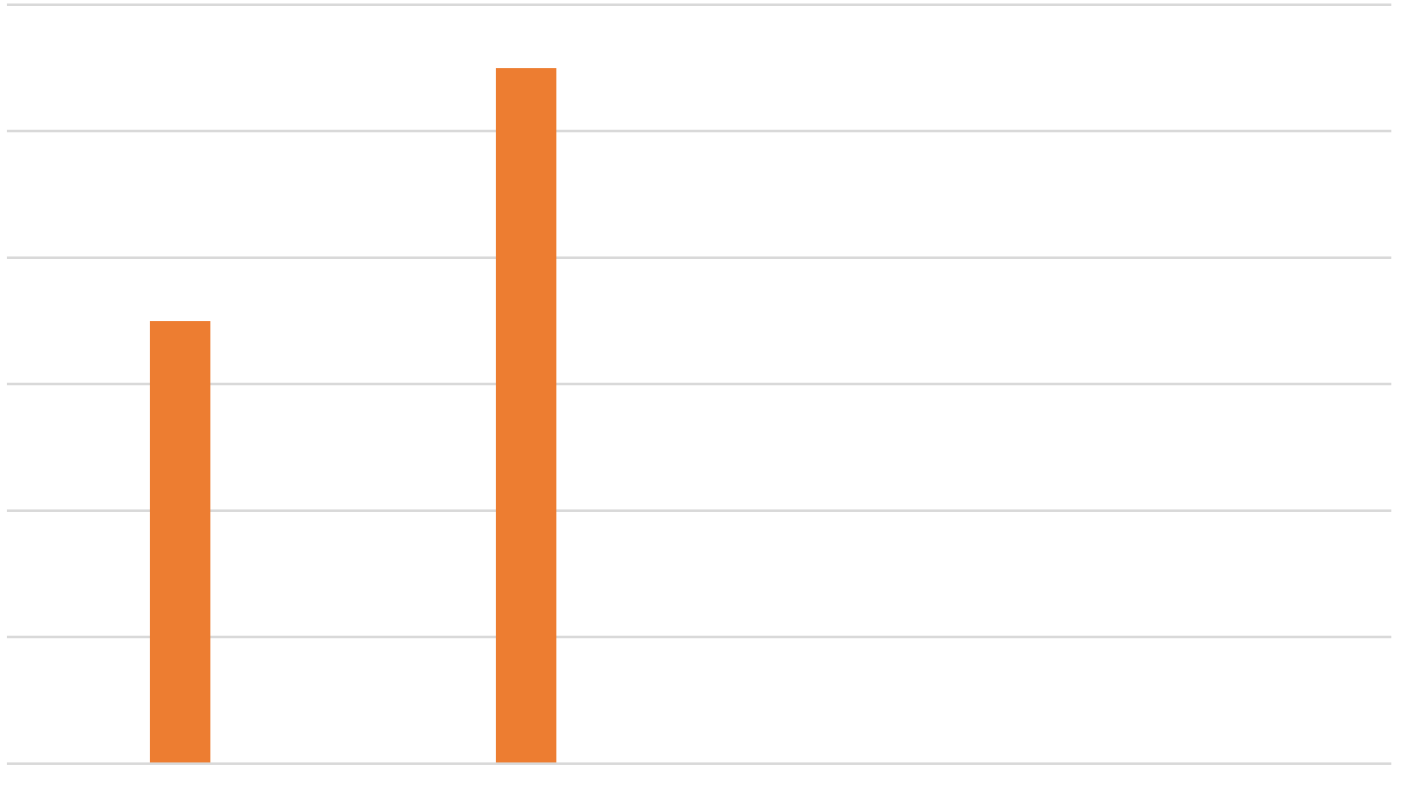

Right sided Breast Lump Left sided Breast Lump

Figure 1. Left sided Breast lumps were commoner as depicted above. 